\title{
Mineralogical and Geochemical Constraints on the Origin of Mafic-Ultramafic-Hosted Sulphides: The Pindos Ophiolite Complex
}

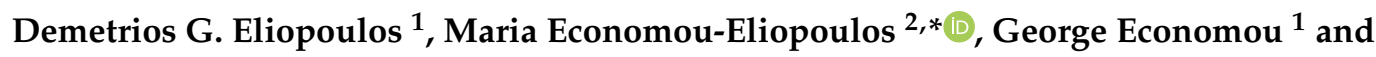 \\ Vassilis Skounakis ${ }^{2}$ \\ 1 Institute of Geology and Mineral Exploration (IGME), Sp. Loui 1, Olympic Village, \\ GR-13677 Acharnai, Greece; eliopoulos@igme.gr (D.G.E.); Georgeoik7@gmail.com (G.E.) \\ 2 Department of Geology and Geoenvironment, University of Athens, 15784 Athens, Greece; \\ vskoun@geol.uoa.gr \\ * Correspondence: econom@geol.uoa.gr
}

Received: 16 April 2020; Accepted: 13 May 2020; Published: 18 May 2020 updates

\begin{abstract}
Sulphide ores hosted in deeper parts of ophiolite complexes may be related to either primary magmatic processes or links to hydrothermal alteration and metal remobilization into hydrothermal systems. The Pindos ophiolite complex was selected for the present study because it hosts both Cyprus-type sulphides (Kondro Hill) and $\mathrm{Fe}-\mathrm{Cu}-\mathrm{Co}-\mathrm{Zn}$ sulphides associated with magnetite (Perivoli-Tsoumes) within gabbro, close to its tectonic contact with serpentinized harzburgite, and thus offers the opportunity to delineate constraints controlling their origin. Massive Cyprus-type sulphides characterized by relatively high $\mathrm{Zn}, \mathrm{Se}, \mathrm{Au}, \mathrm{Mo}, \mathrm{Hg}$, and $\mathrm{Sb}$ content are composed of pyrite, chalcopyrite, bornite, and in lesser amounts covellite, siegenite, sphalerite, selenide-clausthalite, telluride-melonite, and occasionally tennantite-tetrahedrite. Massive $\mathrm{Fe}-\mathrm{Cu}-\mathrm{Co}-\mathrm{Zn}$-type sulphides associated with magnetite occur in a matrix of calcite and an unknown $(\mathrm{Fe}, \mathrm{Mg})$ silicate, resembling $\mathrm{Mg}$-hisingerite within a deformed/metamorphosed ophiolite zone. The texture and mineralogical characteristics of this sulphide-magnetite ore suggest formation during a multistage evolution of the ophiolite complex. Sulphides (pyrrhotite, chalcopyrite, bornite, and sphalerite) associated with magnetite, at deeper parts of the Pindos (Tsoumes), exhibit relatively high $\mathrm{Cu} /(\mathrm{Cu}+\mathrm{Ni})$ and $\mathrm{Pt} /(\mathrm{Pt}+\mathrm{Pd})$, and low Ni/Co ratios, suggesting either no magmatic origin or a complete transformation of a preexisting magmatic assemblages. Differences recorded in the geochemical characteristics, such as higher $\mathrm{Zn}, \mathrm{Se}, \mathrm{Mo}, \mathrm{Au}, \mathrm{Ag}, \mathrm{Hg}$, and $\mathrm{Sb}$ and lower Ni contents in the Pindos compared to the Othrys sulphides, may reflect inheritance of a primary magmatic signature.
\end{abstract}

Keywords: sulphides; ophiolites; ultramafic; selenium; gold; Pindos

\section{Introduction}

Traditionally, the sulphide mineralization associated with ophiolite complexes is that of Cyprus-type volcanogenic massive sulphide (VMS) deposits. They may be derived from the interaction of evolved seawater with mafic country rocks, under greenschist facies metamorphic conditions and subsequent precipitation on and near the seafloor, when ore-forming fluids are mixed with cold seawater [1-5]. They are associated with basaltic volcanic rocks and are important sources of base and trace metals ( $\mathrm{Co}, \mathrm{Sn}, \mathrm{Se}, \mathrm{Mn}, \mathrm{Cd}, \mathrm{In}, \mathrm{Bi}, \mathrm{Te}, \mathrm{Ga}$, and $\mathrm{Ge}$ ) [1]. Massive sulphide deposits have been described in the Main Uralian Fault Zone (Ivanovka and Ishkinino deposits), southern Urals; they are mafic-ultramafic-hosted VMS deposits and show mineralogical, compositional, and textural analogies with present-day counterparts on ultramafic-rich substrates [6]. Recently, an unusual association 
of magnetite with sulphides of Cyprus-type VMS deposit was described in Ortaklar, hosted in the Koçali Complex, Turkey, which is part of the Tethyan Metallogenetic Belt [7]. Additionally, the largest magnetite deposit in a series of apatite and sulphide-free magnetite orebodies hosted in serpentinites of Cogne ophiolites, in the Western Alps, Italy, is characterized by typical hydrothermal compositions [8].

Although the $\mathrm{Fe}-\mathrm{Cu}-\mathrm{Ni}-\mathrm{Co}$-sulphide mineralization was initially considered an unusual type in ophiolite complexes, several occurrences have been located, like those in pyroxenite cumulates of the Oregon ophiolite [9], in dunites associated with chromitites of the Acoje ophiolite, Philippines [10], in layered gabbros of the Oman ophiolite [11], in dunites of the upper mantle-crust transition zone of the Bulqiza (Ceruja, Krasta), Albania ophiolite [12], Shetland (Unst), UK ophiolite [13], and the Moa-Baracoa ophiolitic massif (Cuba) [14]. On the basis of magmatic texture features and steep positive chondrite-normalized Platinum-Group Elements (PGE) patterns, sulphide mineralization of that type has been interpreted as reflecting the immiscible segregation of sulphide melts $[9,13,14]$. Moreover, the occurrence of $\mathrm{Fe}-\mathrm{Ni}-\mathrm{Cu} \pm \mathrm{Zn}$-sulphide mineralization (with dominant minerals pyrrhotite, chalcopyrite, and minor pentlandite) in mantle serpentinized peridotites and mafic to ultramafic rocks of ophiolite complexes of Limassol, Cyprus, Othrys (Eretria) in Greece, Pindos (Tsoumes) ophiolite and elsewhere has been the topic of research for extensive studies [15-20]. On the other hand, texture and geochemical characteristics, including PGE contents, and a very low partition coefficient for Ni and Fe between olivine and sulphides are inconsistent with sulphides having an equilibrium with Ni-rich host rocks at magmatic temperature $[16,18]$. Although the initial magmatic origin is not precluded, present characteristics of the highly transformed ore at the Eretria (Othrys) area may indicate that the magmatic features have been lost or that metals were released from the host rocks by a low-level hydrothermal circulation process [16]. Fe-Cu-Zn-Co-Ni mineralization is also reported in seafloor VMS deposits from modern oceans (as well as in their possible analogues on several ophiolites on land, e.g., Urals) indicating that these deposits can be formed by purely hydrothermal processes [19].

Despite the extensive literature data on a diverse array of sulphide mineralizations, sulphide ores hosted in mafic-ultramafic ophiolitic rocks are characterized by structure as well as mineralogical and geochemical features, suggesting either magmatic origin or links to serpentinization processes and metal remobilization from primary minerals into hydrothermal systems. The present study is focused on some new SEM/EDS and geochemical data on Cyprus-type and $\mathrm{Fe}-\mathrm{Cu}-\mathrm{Co}-\mathrm{Zn}$-type sulphides hosted in deeper parts of the Pindos ophiolite complex, aiming to improve our understanding of the factors controlling trace element incorporation into sulphide minerals and their origin.

\section{Materials and Methods}

\subsection{Mineral Chemistry}

Polished sections (20 samples) from sulphide ores were carbon-coated and examined by a scanning electron microscope (SEM) using energy-dispersive spectroscopy (EDS). The SEM images and EDS analyses were carried out at the University of Athens (NKUA, Athens, Greece), using a JEOL JSM 5600 scanning electron microscope (Tokyo, Japan), equipped with the ISIS 300 OXFORD automated energy-dispersive analysis system (Oxford, UK) under the following operating conditions: accelerating voltage $20 \mathrm{kV}$, beam current $0.5 \mathrm{nA}$, time of measurement (dead time) $50 \mathrm{~s}$, and beam diameter $1-2 \mu \mathrm{m}$. The following X-ray lines were used: $\mathrm{FeK} \alpha, \mathrm{NiK} \alpha, \mathrm{CoK} \alpha, \mathrm{CuK} \alpha, \mathrm{CrK} \alpha, \mathrm{AlK} \alpha, \mathrm{TiK} \alpha, \mathrm{CaK} \alpha, \operatorname{SiK} \alpha$, $\mathrm{MnK} \alpha$, and $\mathrm{MgK} \alpha$. Standards used were pure metals for the elements $\mathrm{Cr}, \mathrm{Mn}, \mathrm{Mo}, \mathrm{Ni}, \mathrm{Co}, \mathrm{Zn}, \mathrm{V}$, and $\mathrm{Ti}$, as well as $\mathrm{Si}$ and $\mathrm{MgO}$ for $\mathrm{Mg}$ and $\mathrm{Al}_{2} \mathrm{O}_{3}$ for $\mathrm{Al}$.

\subsection{Whole Rock Analysis}

The studied sulphide samples were massive and disseminated mineralizations, derived from large (weighing approximately $2 \mathrm{~kg}$ ) samples, which is necessary to obtain statistical representative trace element distribution in sulphide ores. They were crushed and pulverized in an agate mortar. Major and minor/trace elements were determined at the SGS Global-Minerals Division Geochemistry 
Services Analytical Laboratories Ltd., Vancouver, BC, Canada. The samples were dissolved using sodium peroxide fusion, combined Inductively Coupled Plasma and Atomic Emission Spectrometry, ICP-AES and Mass Spectrometry, ICP-MS (Package GE_ICP91A50). On the basis of the quality control report provided by Analytical Labs, the results of the reference material analysis in comparison to expected values, and the results from the multistage analysis of certain samples, showed an accuracy and a precision of the method in good agreement with the international standard $(<10 \%)$.

\section{A Brief Outline of Characteristics for the Studied Sulphides}

The Pindos ophiolite complex, of Middle to Upper Jurassic age, is located in the northern-western part of Greece $\left(49^{\circ} \mathrm{N}, 21^{\circ} \mathrm{E}\right)$, lies tectonically over Eocene flysch of the Pindos zone, and contains a spectrum of lavas from Mid-Ocean Ridge, MOR basalts through island arc tholeiites (IATs) to boninite series volcanics (BSVs) [21-23]. Two tectonically distinct ophiolitic units can be distinguished: (a) the upper unit (Dramala Complex), including mantle harzburgites, and (b) a lower unit, including volcanic and subvolcanic sequences at the Aspropotamos Complex (Figure 1). This complex consists of a structurally dismembered sequence of ultramafic and mafic cumulate ophiolitic rocks, including gabbros, which is locally underlain by sheets of serpentinite [21,22]. Sulphide mineralization in the Pindos ophiolite complex is located near the Aspropotamos dismembered ophiolite unit, belonging to the lower ophiolitic unit of the complex and includes the following.

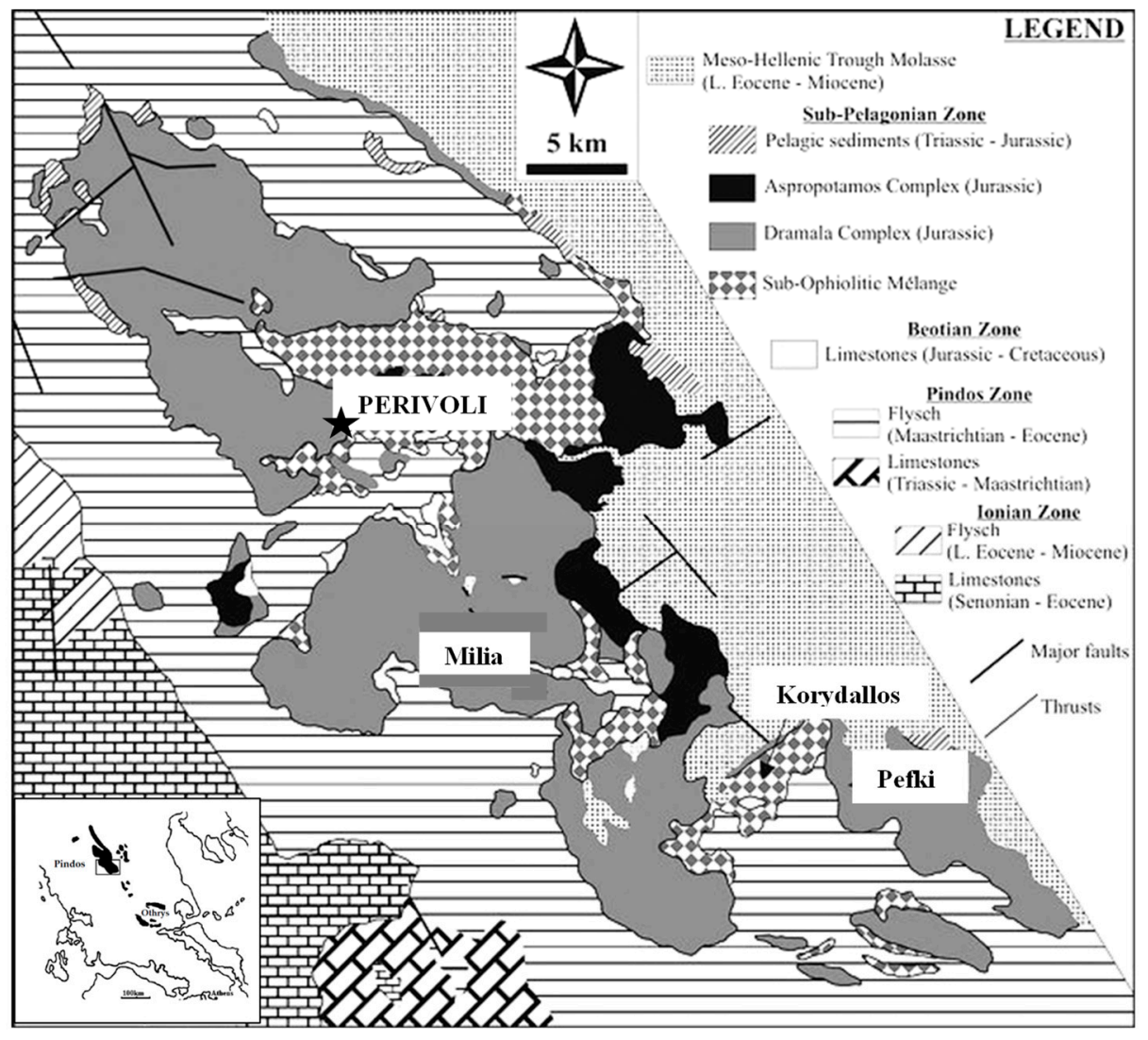

Figure 1. Simplified geological map of the southern part of the Pindos ophiolite, showing the Perivoli (Tsoumes-Kondro) area (modified after [22,24]).

A volcanic and subvolcanic sequence composed mainly of basalts and basaltic andesite pillow lavas ranging from high to low Ti affinity [20-24]. The different magmatic groups may have been derived from different mantle sources and/or various degrees of partial melting [20-24]. Massive Cyprus-type sulphide ore occurrences in the form of small lenses (maximum $4 \times 40 \mathrm{~m}$ ), are located in an abandoned mine, at the Kondro Hill, very close to the village of Perivoli (Figure 1). The estimated ore 
potential is about 10,000 tons with an average $6.6 \mathrm{wt.} \% \mathrm{Cu}$ and $9.4 \mathrm{wt} . \% \mathrm{Zn}$ [25]. They occur on the top of diabase (massive or pillow lavas) and are directly overlain by metalliferous (Fe-Mn-oxide-bearing sediments). Due to the tectonic disruption of the Aspropotamos unit, the spatial association between massive and stockwork disseminated mineralization is unclear.

Several sub-vertical veins of quartz with veinlets and a brecciated pipe-shaped diabase dike (stockwork ore zone) have been described in the Neropriona area of the Aspropotamos unit, Kondro Hill, with disseminations of pyrite + chalcopyrite, and dominant mineral-altered plagioclase and clinopyroxene, penninite, kaolinite, quartz, epidote, and calcite [20,25-27]. Small irregular to lens-like occurrences $(4 \times 1.5 \mathrm{~m})$ of massive $\mathrm{Fe}-\mathrm{Cu}-\mathrm{Zn}$-Co-type sulphide mineralization associated with magnetite are exposed at the Perivoli (Tsoumes) Hill (Figure 1). These are hosted within gabbro, close to its contact with serpentinized harzburgite $[20,25]$, consisting of pyrrhotite, pyrite, chalcopyrite, and sphalerite associated with magnetite. The contact between ore and hosting rock is not sharp, appearing as irregular nets of veinlets. Rounded fragments of highly altered rock and massive fragments of sulphide ore are broadly parallel to the shear plane of a thrust fault.

\section{Mineralogical Features}

\subsection{Cyprus-Type Sulphides}

The massive ore is mainly composed of pyrite, chalcopyrite, bornite, and in lesser amounts covellite, siegenite, sphalerite, and clausthalite, while pyrrhotite is lacking (Figure 2). Chalcopyrite, bornite, and sphalerite occur in at least two different generations. Pyrite grains vary from euhedral to subhedral and rarely framboidal. Textural relationships indicate that early pyrite, commonly occurring as large crystals but often exhibiting dissolution, is extensively penetrated and replaced by fine-grained chalcopyrite, bornite, and sphalerite in a matrix of quartz (Figure 2). Copper-bearing sphalerite, with up to $3.6 \mathrm{wt} . \% \mathrm{Fe}, 4.2 \mathrm{wt} . \% \mathrm{Cu}$, and $1.7 \mathrm{wt} . \% \mathrm{Bi}$, occurs within pyrite crystals and/or cements minor chalcopyrite and pyrite (Figure $2 \mathrm{~b}, \mathrm{e}, \mathrm{f}$; Table 1 ). Pyrite is extensively replaced by intergrowths between chalcopyrite or bornite and Fe-poor sphalerite (Figure 2b,d; Figure 3) and occasionally contains Co (Table 1). Fine-grained intergrowths of framboidal or colloform pyrite-bornite, occurs in a matrix of quartz (Figure 2g,h). Fine-grained chalcopyrite or bornite are often found in cross-cutting veins, hosting selenides (mainly clausthalite, $\mathrm{PbSe}$ ) (Table 1 ), the telluride mineral melonite $\left(\mathrm{NiTe}_{2}\right)$, gold, galena, and barite [26]. Furthermore, present investigation reveals the formation of aggregates of secondary minerals, occurring as characteristic crusts on bornite surfaces (Figure 2i-1). These minerals are present-day grown minerals, on the surface of polished sections of sulphide ore, exposed to air, under room conditions $\left(20-25^{\circ} \mathrm{C}\right)$ and moderate air humidity (atmospheric water). Gold, as inclusions in chalcopyrite reaching a maximum size of $20 \mu \mathrm{m}$ with $\mathrm{Ag}$ contents of up to $9 \mathrm{wt} . \%$, is a rare component of the ores [26]. Additionally, we observed the presence of submicroscopic gold, i.e., $<1 \mu \mathrm{m}$ and thus invisible under an optical microscope, in grains of pyrite, chalcopyrite, and bornite, that increases with decreasing crystal size, reaching contents up to $7.7 \mathrm{ppm}$ Au in pyrite, $8.8 \mathrm{ppm}$ Au in very fine intergrowths between pyrite and sphalerite, and $17.3 \mathrm{ppm} \mathrm{Au}$ in fine intergrowths between pyrite and bornite [20]. 


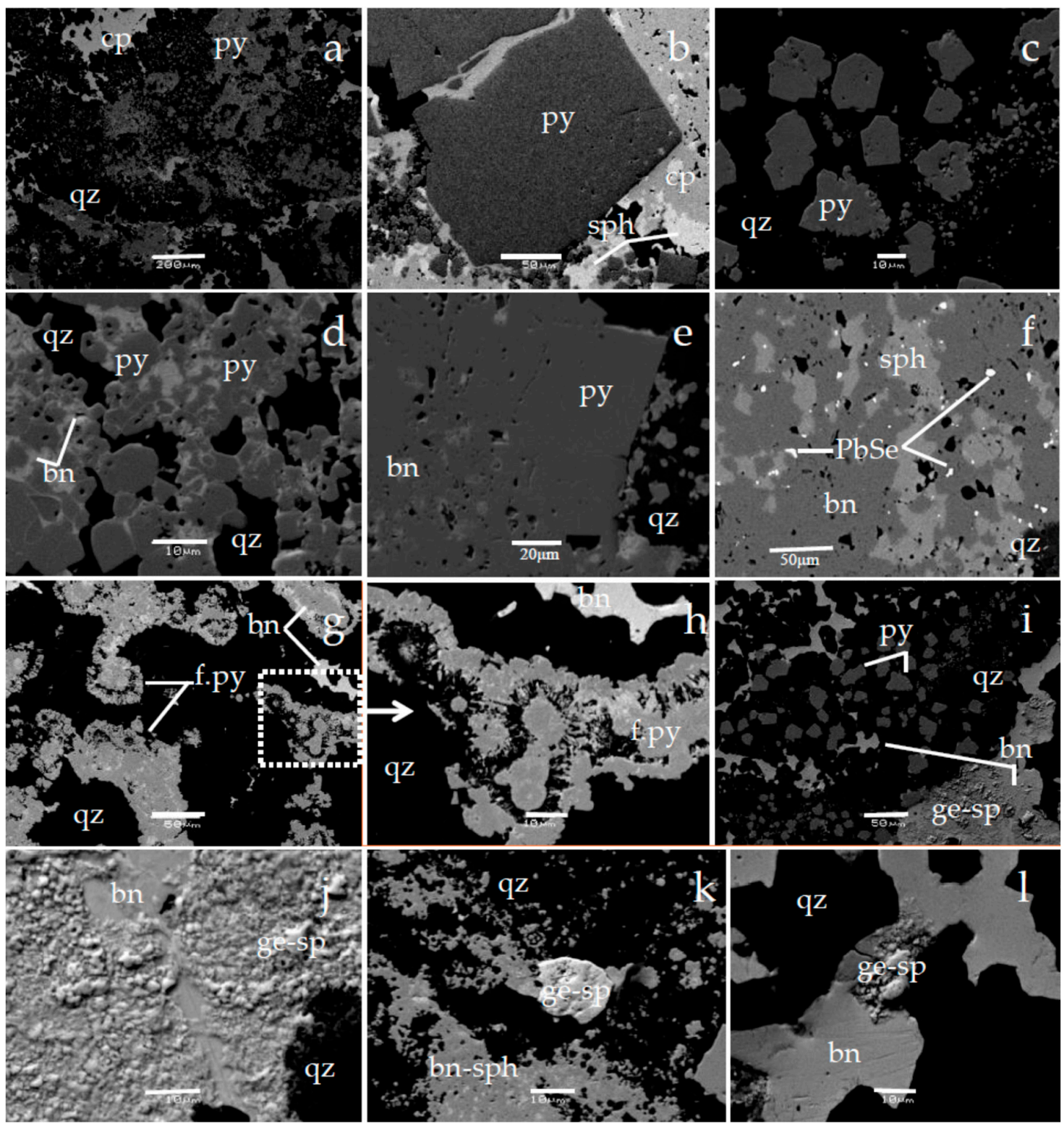

Figure 2. Backscattered electron (BSE) images representative of various morphological forms and textures of pyrite associated with chalcopyrite and sphalerite in a matrix of quartz (a-d); euhedral pyrite displaying erosion and replacement by chalcopyrite-sphalerite intergrowths (b); a close intergrowth between pyrite and bornite (d,e); selenides (clausthalite) as inclusions within bornite (f); fine-grained intergrowths of framboidal or colloform pyrite-bornite, in a matrix of quartz $(\mathbf{g}, \mathbf{h})$; replacement of bornite by neo-formed intergrowths of $\mathrm{Cu}$ minerals (i-1), which are $\mathrm{Cu}$-enriched and Fe-depleted (Table 1). Scale bar: $200 \mu \mathrm{m}(\mathbf{a}) ; 50 \mu \mathrm{m}(\mathbf{b}, \mathbf{f}, \mathbf{g}, \mathbf{i}) ; 20 \mu \mathrm{m}(\mathbf{e}) ; 10 \mu \mathrm{m}(\mathbf{c}, \mathbf{d}, \mathbf{h}, \mathbf{j}, \mathbf{k}, \mathbf{l})$. Abbreviations: py = pyrite; $\mathrm{cp}=$ chalcopyrite; $\mathrm{sph}=$ sphalerite bn = bornite; PbSe = clausthalite; qz = quartz; f.py = framboidal forms of pyrite with tiny inclusions of $\mathrm{Cu}$ minerals; ge-sp = intergrowths of neo-formed $\mathrm{Cu}$ minerals with composition corresponding to geerite and spionkopite. 
Table 1. Representative SEM/EDS analyses of minerals from the Pindos sulphide ores. (n.d.: Lower than detection limit).

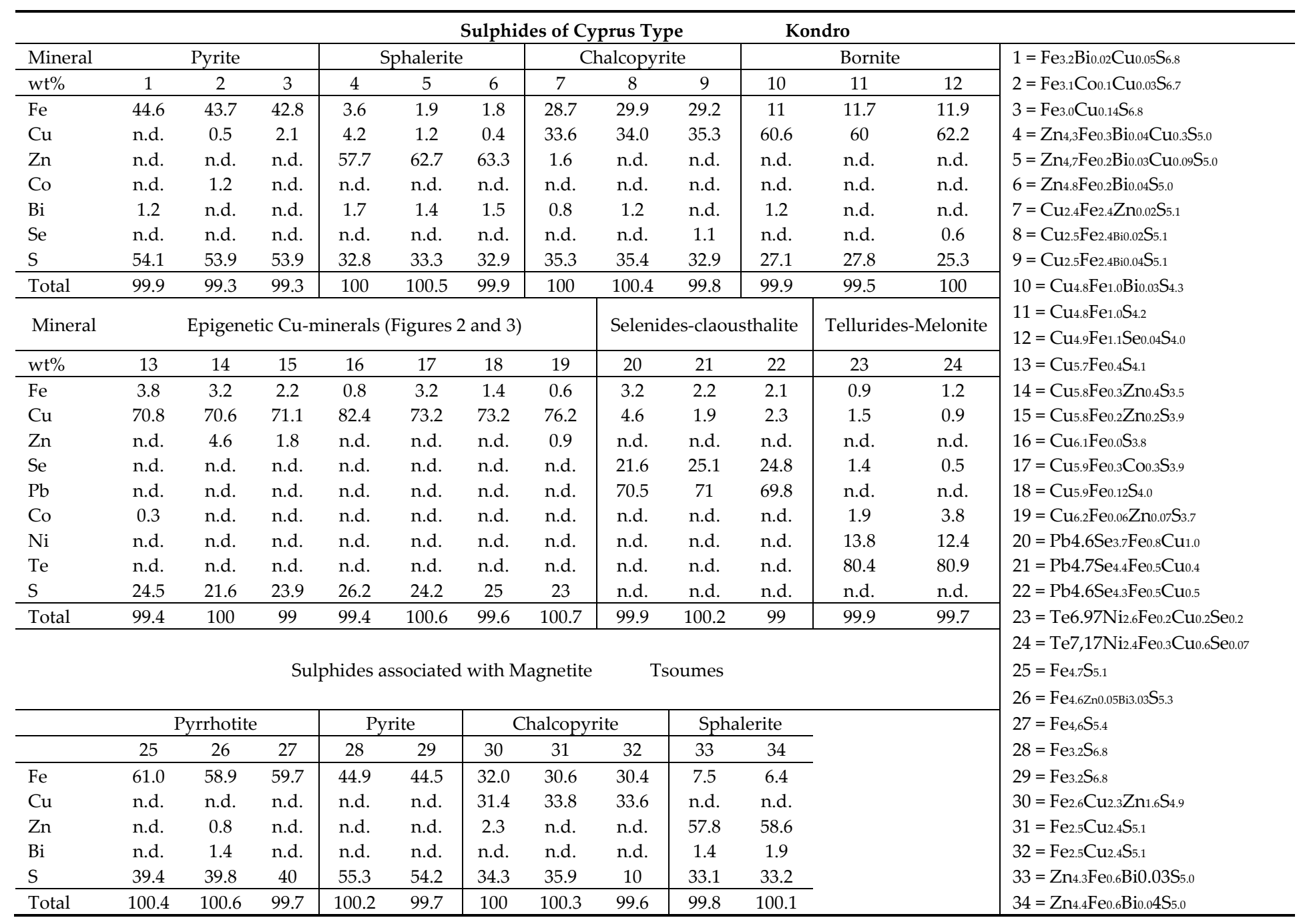



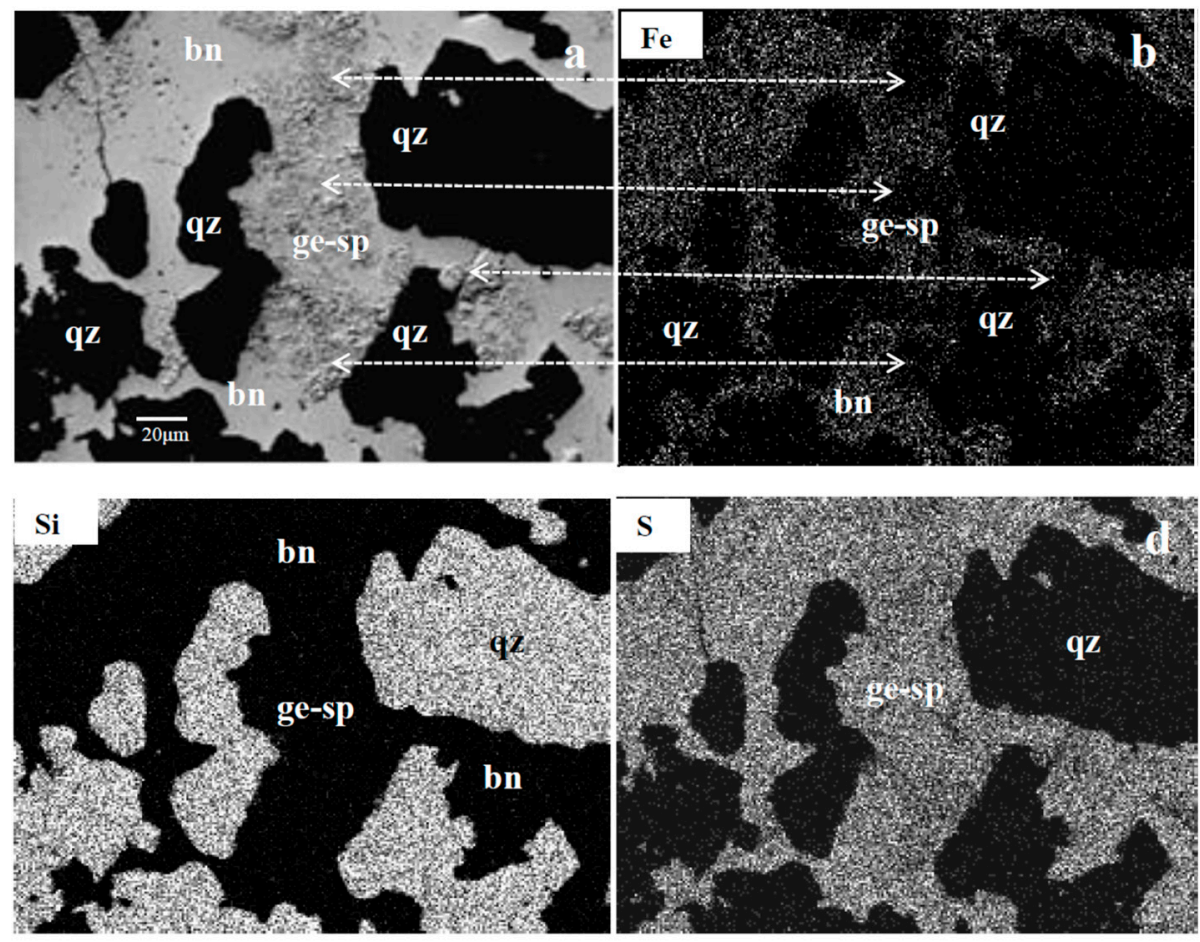

Figure 3. Backscattered electron (BSE)images showing bornite, partially replaced by neo-formed intergrowths of epigenetic minerals resembling geerite or spionkopite, in a matrix of quartz (a) and the single scanning for Fe (b), Si (c), and S (d). White arrows indicate the Fe depletion in the present-day formed intergrowths of high Cu minerals. Symbols, as in Figure 2. Scale bar for b, c, d as in 3a (20 $\mu \mathrm{m})$

\subsection{Breccia Pipe}

Disseminated pyrite, minor chalcopyrite, and sphalerite occur mostly in vesicles filled by quartz, kaolinite, chlorite, and epidote, within brecciated pipe-form diabase (a discharge pathway) underlying the Kondro massive ore [27]. Samples $(n=10)$ of pyrite separates from the diabase breccia have shown a limited range for $\delta^{34} \mathrm{~S}$ values from +1.0 to $+1.5 \%$ [27].

\subsection{Massive $\mathrm{Fe}-\mathrm{Cu}-\mathrm{Co}-\mathrm{Zn}$-Type Sulphides Associated with Magnetite}

The sulphide ore is mainly composed of pyrrhotite, while pyrite, chalcopyrite, sphalerite, malachite, and azurite are present in lesser amounts. Pure magnetite, often forming a network texture, is associated with sulphides, either as massive ore with inclusions of sulphides (chalcopyrite, pyrite, and pyrrhotite), or as individual grains dispersed within sulphide ore (Figure 4). A characteristic feature of magnetite is its elongated and curved form and its textural relationship with the sulphides. Pyrrhotite, which is the most abundant sulphide, is followed by chalcopyrite and sphalerite, all showing an irregular contact with the magnetite, that often occurs surrounding sulphides (Figure 4a-c). Additionally, a salient feature is the occurrence of an $(\mathrm{Fe} / \mathrm{Mg})$ phyllosilicate associated with sphalerite, chalcopyrite, and magnetite (Figure 4d-f; Figure 5). 


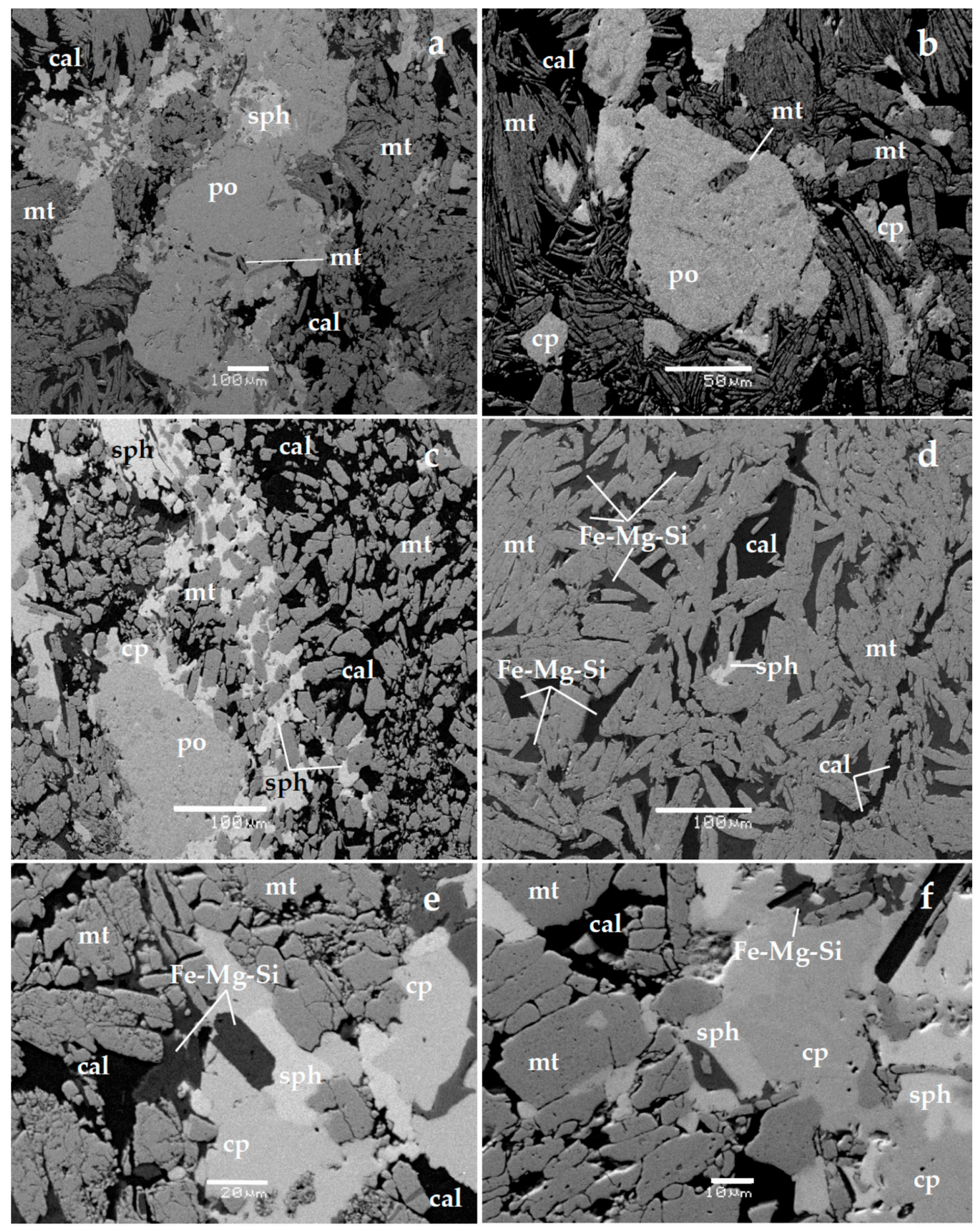

Figure 4. Backscattered electron (BSE) images showing intergrowths between pyrrhotite, sphalerite, and magnetite in a matrix of calcite (a); elongated curved crystals of magnetite and inclusions within pyrrhotite (b); intergrowths between pyrrhotite, sphalerite, chalcopyrite, and magnetite in a matrix of calcite (c); magnetite associated with sphalerite in a matrix of calcite and $(\mathrm{Fe}, \mathrm{Mg})$ silicate $(\mathrm{d})$; sphalerite adjacent to chalcopyrite with inclusions of $(\mathrm{Fe}, \mathrm{Mg})$ silicate $(\mathbf{e})$; transitional contact between chalcopyrite and sphalerite and their intergrowths with magnetite (f) Scale bar: $100 \mu \mathrm{m}(\mathbf{a}, \mathbf{c}, \mathbf{d}) ; 50 \mu \mathrm{m}(\mathbf{b}) ; 20 \mu \mathrm{m}(\mathbf{e})$; $10 \mu \mathrm{m}(\mathbf{f})$. Symbols: cal = calcite; $\mathrm{Fe}-\mathrm{Mg}-\mathrm{Si}=(\mathrm{Fe}, \mathrm{Mg})$ silicate, and as in Figure 2. 

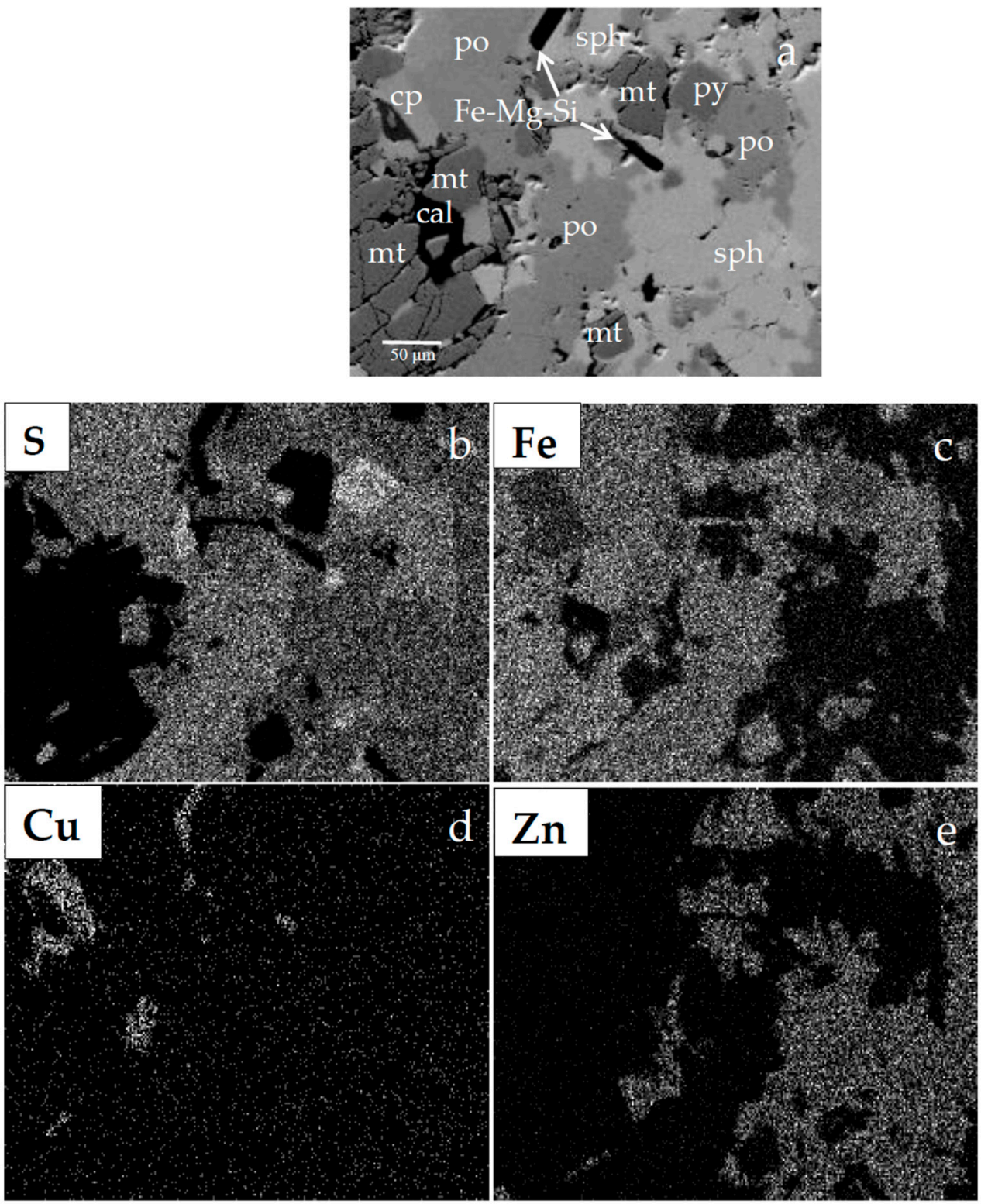

Figure 5. Backscattered electron (BSE) images showing intergrowths of pyrrhotite, pyrite, chalcopyrite, and sphalerite in a matrix of calcite and an unknown (Fe-Mg) silicate (a), Table 2; single scanning for $\mathrm{S}$

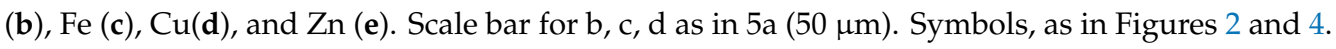

Table 2. Representative SEM/EDS analyses of $(\mathrm{Fe}, \mathrm{Mg})$ silicates from the Tsoumes massive sulphides.

\begin{tabular}{ccccc}
\hline wt \% & $\begin{array}{c}\text { Tsoumes } \\
\text { (Fe,Mg)-Silicate }\end{array}$ & \multicolumn{3}{c}{ Laramie Complex [28] } \\
Hisingerite \\
\hline $\mathrm{SiO}_{2}$ & 35 & 33.2 & 42.7 & 37.8 \\
$\mathrm{Al}_{2} \mathrm{O}_{3}$ & 0.9 & 1.1 & 1.2 & 0.03 \\
$\mathrm{Cr}_{2} \mathrm{O}_{3}$ & n.d. & n.d. & 0.03 & 0.04 \\
$\mathrm{Fe}_{2} \mathrm{O}_{3 \mathrm{t}}$ & 42.3 & 43.2 & 35.83 & 46.94 \\
$\mathrm{MnO}$ & n.d. & n.d. & 0.15 & 0.49 \\
$\mathrm{MgO}$ & 11.9 & 12.1 & 7.46 & 2.15 \\
$\mathrm{NiO}$ & n.d. & n.d. & 0.05 & 0.01 \\
$\mathrm{CaO}$ & n.d. & n.d. & 0.81 & 0.39 \\
\hline $\mathrm{Total}$ & 90.1 & 89.6 & 88.22 & 87.85 \\
\hline
\end{tabular}




\section{Geochemical Characteristics of Sulphides}

Massive sulphide ores from the Kondro Hill exhibit uncommon high contents in Au (up to $3.6 \mathrm{ppm}$ ), Ag (up to $56 \mathrm{ppm}$ ), Se (up to $1900 \mathrm{ppm}$ ), Co (up to $2200 \mathrm{ppm}$ ), Mo (up to $370 \mathrm{ppm}$ ), $\mathrm{Hg}$ (up to $280 \mathrm{ppm}$ ), $\mathrm{Sb}$ (up to $10 \mathrm{ppm}$ ), and As up to $150 \mathrm{ppm}$, which are much higher than those in the $\mathrm{Fe}-\mathrm{Cu}-\mathrm{Zn}-\mathrm{Co}$-type sulphide hosted in ultramafic parts of the complex, along a shearing zone, close to a contact with gabbros (Table 3), as well as within brecciated pipe-form diabase (a discharge pathway) underlying the Kondro massive ore [20]. Major and minor elements, such as $\mathrm{Fe}, \mathrm{Cu}$, and $\mathrm{Zn}$, are hosted in sulphides (pyrrhotite and pyrite, chalcopyrite, bornite, and epigenetic high $\mathrm{Cu}$ minerals, and sphalerite, respectively). Magnetite and Fe silicates (Tables 1 and 2), selenides, tellurides, gold, galena, and barite are occasionally present, but Mo-bearing minerals were not identified.

Major and trace elements in massive sulphide ores of Cyprus- and $\mathrm{Fe}-\mathrm{Cu}-\mathrm{Co}-\mathrm{Zn}$-type sulphides from the Pindos ophiolite complex, along with those from comparable ophiolites such as the Othrys and Troodos ophiolite complexes [29-33], are plotted in Figure 6. Although there are overlapping fields, it seems likely that the Pindos sulphides can be distinguished by their higher Zn (Figure 6a,c) and $\mathrm{Co}$ (Figure 6b) contents (Figure 6). The highest Se contents were recorded in the Pindos and the Apliki ores (Cyprus) accompanied by $\mathrm{Cu}$ and Au contents (Figure $6 \mathrm{~d}, \mathrm{e}$ ). A positive trend is also clear between $\mathrm{Au}$ and As (Figure 6f). 


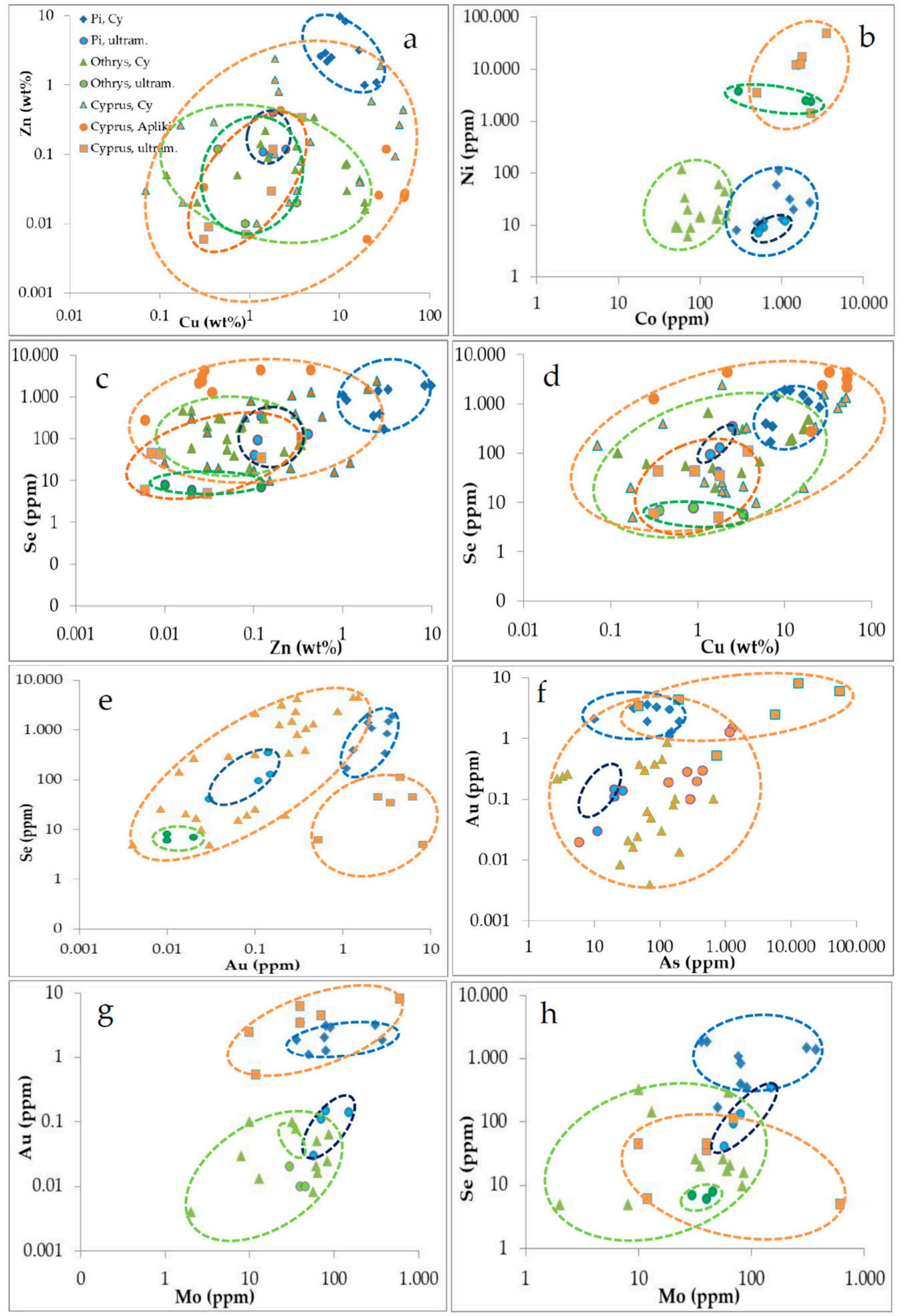

Figure 6. Plots of major and trace elements of Cyprus-type (labeled as Cy) sulphide ores and $\mathrm{Fe}-\mathrm{Cu} \pm \mathrm{Co} \pm \mathrm{Zn}$ sulphides hosted in ultramafic rocks (labeled as ultram.) from the Pindos (Pi), Othrys, and Troodos ophiolite complexes. Although there are overlapping fields, the ores from the Pindos can be distinguished for the presence of ores with higher $\mathrm{Zn}(\mathbf{a}, \mathbf{c})$ and $\mathrm{Co}(\mathbf{b})$ contents in Cyprus-type ores. The highest Se contents are recorded in the Pindos and the Apliki ores (Cyprus) accompanied by $\mathrm{Cu}$ and Au contents (d,e). A positive trend is also clear between Au and As (f). Data: Table 3; [3,7,16,18,20,29,30]. 
Table 3. Geochemical characteristics of sulphide ores hosted in the Pindos, Othrys, and Troodos ophiolites. Data: present study [20].

\begin{tabular}{|c|c|c|c|c|c|c|c|c|c|c|c|c|c|c|c|}
\hline \multirow{2}{*}{$\begin{array}{l}\text { Location } \\
\text { Description }\end{array}$} & \multirow{2}{*}{$\begin{array}{c}\mathrm{wt} \% \\
\mathrm{Fe}\end{array}$} & \multirow{2}{*}{$\begin{array}{c}\mathrm{wt} \% \\
\mathrm{Cu}\end{array}$} & \multirow{2}{*}{$\begin{array}{c}\mathbf{w t} \% \\
\mathrm{Zn}\end{array}$} & \multicolumn{12}{|c|}{ ppm } \\
\hline & & & & Co & $\mathbf{N i}$ & Mo & Se & As & $\mathrm{Au}$ & $\mathrm{Ag}$ & $\mathrm{Hg}$ & $\mathrm{Sb}$ & $\mathrm{Cu} /(\mathrm{Cu}+\mathrm{Ni})$ & $\mathrm{Ni} / \mathrm{Co}$ & $\mathbf{P t} /(\mathbf{P t}+\mathbf{P d})$ \\
\hline \multicolumn{16}{|l|}{ Pindos } \\
\hline \multirow{9}{*}{ Kondro Massive ore } & 26.9 & 6.9 & 2.9 & 1400 & 20 & 50 & 170 & 140 & 1.1 & 56 & 40 & 9.5 & $>0,99$ & 0.014 & - \\
\hline & 21.2 & 6.1 & 2.6 & 1250 & 32 & 80 & 400 & 150 & 1.3 & 34 & 70 & 7.1 & $>0,99$ & 0.026 & - \\
\hline & 26.5 & 16.4 & 3.2 & 600 & 12 & 310 & 1500 & 90 & 3.3 & 38 & 170 & 8.1 & $>0,99$ & 0.02 & - \\
\hline & 22.5 & 10.1 & 9.8 & 500 & 11 & 40 & 1900 & 64 & 3.6 & 32 & 280 & 10 & $>0,99$ & 0.022 & - \\
\hline & 11.9 & 25.4 & 1.1 & 2200 & 27 & 80 & 850 & 40 & 3.2 & 39 & 60 & 2.1 & $>0,99$ & 0.012 & - \\
\hline & 20.8 & 7.2 & 2.2 & 910 & 110 & 91 & 350 & 140 & 3 & 35 & 48 & 6.6 & $>0,99$ & 0.12 & - \\
\hline & 9.5 & 18.9 & 1 & 870 & 60 & 76 & 1100 & 10 & 2.1 & 40 & 128 & 1.3 & $>0,99$ & 0.07 & - \\
\hline & 26.4 & 11.6 & 8.3 & 280 & 8 & 36 & 1900 & 64 & 1.9 & 38 & 280 & 10 & $>0,99$ & 0.028 & - \\
\hline & 23.2 & 8.1 & 2.5 & 1000 & 13 & 370 & 1400 & 200 & 1.9 & 48 & 168 & 1.4 & $>0,99$ & 0.013 & - \\
\hline \multicolumn{16}{|l|}{ Aspropotamos } \\
\hline \multirow{2}{*}{ Disseminated Diabase breccia } & 7.1 & 0.006 & 0.007 & 27 & $<5$ & $<5$ & $<5$ & 25 & 0.018 & $<1$ & $<1$ & 0.3 & - & - & 0.95 \\
\hline & 6.9 & 0.007 & 0.009 & 15 & $<5$ & $<5$ & $<5$ & 25 & 0.025 & $<1$ & $<1$ & 0.6 & - & - & 0.97 \\
\hline \multirow{4}{*}{ Tsoumes } & 49.8 & 1.8 & 0.4 & 600 & 9 & 80 & 130 & 20 & 0.15 & 6 & 10 & 1 & $>0,99$ & 0.015 & 0.12 \\
\hline & 33.4 & 2.5 & 0.12 & 1100 & 12 & 150 & 350 & 27 & 0.14 & 7 & 30 & 0.8 & $>0,99$ & 0.01 & 0.87 \\
\hline & 31.2 & 1.4 & 0.11 & 540 & 8 & 70 & 95 & 20 & 0.11 & 8 & 11 & 0.9 & $>0,99$ & 0.015 & 0.22 \\
\hline & 30.3 & 1.7 & 0.1 & 520 & 7 & 58 & 41 & 11 & 0.03 & 5 & 16 & 0.4 & $>0,99$ & 0.013 & 0.87 \\
\hline Othrys & 39.4 & 3.3 & 0.02 & 2300 & 2400 & 40 & 6 & 2 & 0.01 & $<1$ & 1 & 0.2 & 0.93 & 1.04 & 0.99 \\
\hline \multirow{2}{*}{ Eretria } & 35.9 & 0.44 & 0.12 & 400 & 3700 & 30 & 7 & $<5$ & 0.02 & $<1$ & 0.3 & 0.2 & 0.49 & 12.33 & 0.61 \\
\hline & 37.4 & 0.89 & 0.01 & 2000 & 2500 & 46 & 8 & $<5$ & 0.01 & $<1$ & 0.6 & 0.2 & 0.78 & 1.25 & 0.86 \\
\hline \multirow{6}{*}{ Cyprus } & 38.8 & 1.8 & 0.12 & 1500 & 12,000 & 40 & 35 & 47 & 3.5 & 2.1 & 2 & 18 & 0.6 & 8 & - \\
\hline & 43.5 & 1.74 & 0.03 & 1800 & 17,100 & 610 & 5 & 12,800 & 8.2 & 8.2 & $<1$ & 73 & 0.5 & 9.5 & - \\
\hline & 43.8 & 3.8 & 0.34 & 2300 & 1400 & 70 & 110 & 190 & 4.5 & 4.5 & $<1$ & 10 & 0.96 & 0.61 & - \\
\hline & 38.7 & 0.91 & 0.007 & 3600 & 48,500 & 40 & 45 & 54,800 & 6.2 & 0.91 & 2 & 94 & 0.66 & 13.5 & 0.95 \\
\hline & 54.4 & 0.35 & 0.009 & 1700 & 12,500 & 10 & 44 & 5600 & 2.5 & 0.35 & 1.5 & 13 & 0.21 & 7.35 & 0.5 \\
\hline & 13.2 & 0.31 & 0.006 & 500 & 3500 & 12 & 6 & 730 & 0.53 & 0.31 & 1 & 6.6 & 0.53 & 7 & 0.61 \\
\hline
\end{tabular}

Symbol _ : Pt contents $<10$ ppb. 


\section{Discussion}

\subsection{A Comparison between Magmatic Sulphides and Those Hosted in Mafic-Ultramafic Ophiolites}

It has been well established that the formation of magmatic deposits is related to the segregation of sulphide melts by immiscibility from basaltic magmas, which are able to collect precious metals (PGE, Ag, $\mathrm{Au}$ ) as well as other chalcophile elements (Se, Te, Bi, Pb, As, Sb) because of their high partition coefficient ( $\mathrm{D}_{\text {sulphide melt/silicate melt }}$ [34,35]. The compositions of the magmatic ores may be mainly controlled by (a) the metal abundances of the mantle source and the degree of partial melting [36,37], (b) the degree of fractional crystallization and potential crustal contamination during magma ascent [38], and (c) interactions with magmatic-hydrothermal or metamorphic-hydrothermal fluids [39-41]. Compositional data obtained from a large number of magmatic sulphide deposits [42] show clear differences from the $\mathrm{Fe}-\mathrm{Cu} \pm \mathrm{Co} \pm \mathrm{Zn} \pm$ Ni-sulphide mineralization hosted in ophiolite complexes.

The unusual Fe-Cu-Ni-Co type of sulphides hosted in mafic-ultramafic ophiolitic rocks is characterized by varying structural, mineralogical, and geochemical features, which are not of magmatic origin. Sulphides hosted in the magmatic sequence of ophiolite complexes [9-14] have been interpreted as reflecting the immiscible segregation of sulphide melts, because they exhibit magmatic texture features and steep positive chondrite-normalized PGE patterns [9-14]. However, the Pindos (Tsoumes) Fe-Cu-Co-Zn-sulphides, consisting mainly of pyrrhotite, chalcopyrite, bornite, and sphalerite and hosted within gabbro, close to its tectonic contact with serpentinized harzburgite, differ compared to the Othrys (Eretria) sulphides, which are located at the peripheries of podiform chromite bodies hosted in serpentinized harzburgite and consist of pyrrhotite, chalcopyrite, and minor Co-pentlandite. Furthermore, the Pindos massive sulphides differ from those in the serpentinized rocks of the Limassol Forest (Troodos), which are composed dominantly of troilite, maucherite, pentlandite, chalcopyrite, bornite, vallerite, magnetite, minor sphalerite, graphite, molybdenite, and gold. In addition, the sulphides in the Limassol Forest contain much higher Au and As, up to 8 and 62 ppm, respectively [15,18], compared to the Pindos sulphides (Table 3). Despite the above differences between the Pindos, Othrys, and Limassol sulphides, they are all characterized by higher $\mathrm{Cu} /(\mathrm{Cu}+\mathrm{Ni})$ ratios $(>0.99,0.5-0.93$, and 0.2-0.96, respectively) compared to most magmatic deposits, having $\mathrm{Cu} /(\mathrm{Cu}+\mathrm{Ni})$ ratios ranging from 0.05 to 0.14 [42]. In addition, the $\mathrm{Ni} / \mathrm{Co}$ ratio in magmatic deposits typically ranges from 15 to 50 [42], whereas the range of Ni/Co ratio is 1.0-12 for the Eretria, 0.6-14 for the Limassol, and 0.01-0.02 for the Pindos (Tsoumes) samples (Table 3).

Model calculations have shown that the relatively high Co tenor and low Ni/Co cannot be explained by an earlier phase of fractional crystallization or sulphide segregation [43]. Thus, the higher $\mathrm{Ni}$ and Co contents in sulphide occurrences associated with chromitite bodies in the Othrys (Eretria) peridotites may suggest re-mobilization of $\mathrm{Fe}, \mathrm{Co}$, and $\mathrm{Ni}$ during hydrothermal alteration of peridotite in the presence of aqueous $\mathrm{H}_{2} \mathrm{~S}$, and precipitation of $\mathrm{Ni}-\mathrm{Co}-\mathrm{Fe}$ sulphides [44,45]. The presence of graphite-like material in chromitites associated with sulphides from the Othrys complex, along shear zones that served as fluid pathways through the chromitites [46,47], may support the mobilization and re-precipitation of Fe-Ni-Co sulphides. Furthermore, the occurrence of phosphides such as Ni-V-Co phosphide [48], $\mathrm{Mo}_{3} \mathrm{Ni}_{2} \mathrm{P}_{1+x}$ [49], NiVP [50], and the associated sulphide $\mathrm{V}_{7} \mathrm{~S}_{8}$ [51] in chromitite concentrates from the Othrys ophiolite are consistent with extremely low $\mathrm{fO}_{2}$ (reducing environment) during serpentinization [51] and re-precipitation of sulphides.

Intergrowths between sulphides and magnetite often forming curved crystals, which reflect a simultaneous deposition, coupled with the occurrence of calcite and an unknown (Fe,Mg) silicate (Figure 4d-f) resembling $\mathrm{Mg}$-hisingerite [52] may provide evidence for the conditions of the Pindos sulphide deposition. Such a $(\mathrm{Fe}, \mathrm{Mg})$ silicate is unusual compared to the common presence of Mg-enriched serpentine in other ophiolite complexes. It seems to be comparable with the secondary phyllosilicates described in altered ferroan metaperidotite ("Oxide Body"), from the Laramie Complex (Laramie city, WY, USA), and serpentinites containing the Si-free minerals, such as brucite and $\mathrm{NiFe}$ alloy (awaruite). Such secondary phyllosilicates contain approximately equal amounts of 
end-members of the serpentine $\left[\left(\mathrm{Mg}, \mathrm{Fe}^{2+}\right)_{3} \mathrm{Si}_{2} \mathrm{O}_{5}(\mathrm{OH})_{4}\right]$ and hisingerite $\left[\mathrm{Fe}^{3+}{ }_{2} \mathrm{Si}_{2} \mathrm{O}_{5}(\mathrm{OH})_{4} \cdot \mathrm{nH}_{2} \mathrm{O}\right][28]$. The substitution of $\mathrm{Fe}^{3+}$ ions into the serpentine structure is crystallographically favorable because of the smaller ionic radius of $\mathrm{Fe}^{3+}$ compared to that of $\mathrm{Mg}^{2+}$ [53]. Moreover, based on a thermodynamic model for hydrothermal alteration in the Fe-silicate system, it has been shown that the formation of serpentine-hisingerite solid solutions after primary olivine may occur at elevated $\mathrm{a}_{\mathrm{SiO} 2(a q)}$ and low $\mathrm{a}_{\mathrm{H} 2(a q)}$ at low temperatures (about $200{ }^{\circ} \mathrm{C}$ ) [28]. In addition, it has been suggested that $\mathrm{H}_{2}$ production is associated with Fe(III) incorporation into serpentine (or magnetite) [54-56].

The association of magnetite with sulphides from the Pindos (Tsoumes) resembles an unusual association of magnetite with sulphides of Cyprus-type ophiolite-hosted VMS deposit in Ortaklar, located in the Koçali Complex, Turkey [7]. They are similar in terms of the deposition order, as suggested by the observed textural relationships: Fe-sulphide (pyrrhotite or pyrite) $\rightarrow$ chalcopyrite $\rightarrow$ sphalerite and subsequently magnetite (Figure 4; [7]) and the $\mathrm{Cu}, \mathrm{Zn}, \mathrm{Pb}$, and $\mathrm{Au}-\mathrm{Ag}$ contents [7]. Such temporal relationships among the primary ore minerals have been attributed to the evolution of ore-forming fluids. Specifically, increasing oxygen fugacity $\left(\mathrm{fO}_{2}\right)$ and $\mathrm{pH}$ would deplete sulphide $\left(\mathrm{H}_{2} \mathrm{~S}\right)$ and facilitate the magnetite precipitation in the hydrothermal fluids [7]. In addition, the Pindos sulphides exhibit similarities with the Cogne magnetite deposit (Western Alps, Italy), which is the largest in a series of apatite and sulphide-free magnetite orebodies that are hosted in serpentinites belonging to western Alpine ophiolitic units [8]. The authors applying thermodynamic modelling of fluid-rock interactions concluded that fractionation processes such as phase separation were critical to generate hydrothermal fluids capable of precipitating large amounts of magnetite in various types of ultramafic host rocks [8]. Although variable textures described in the large Cogne magnetite deposit differ from those in the Pindos magnetite ore, the trace element content of magnetite from the Cogne deposit, characterized by high $\mathrm{Mg}$ and $\mathrm{Mn}$ and low $\mathrm{Cr}, \mathrm{Ti}$, and $\mathrm{V}$ [8], is comparable to those in the Pindos magnetite separates [57]. Additionally, $\mathrm{Fe}-\mathrm{Cu}-\mathrm{Zn}-\mathrm{Co}-\mathrm{Ni}$ mineralization has been reported in seafloor VMS deposits from modern oceans, as well as in their potential analogues on several ophiolite complexes, as exemplified in the Urals, supporting the origin of such deposits by hydrothermal processes [19]. Moreover, hydrothermal products including $\mathrm{Cu}-\mathrm{Zn}-(\mathrm{Co})$-rich massive sulphides, hosted in ultramafic rocks at the Rainbow (Mid-Atlantic Ridge), exhibit structure, mineralogy, and bulk rock chemistry similar to those found in mafic volcanic-hosted massive sulphide deposits [58].

In general, the main factors controlling metal associations in seafloor massive sulphide (SMS) deposits may be the temperature of deposition, seafloor spreading rate and $\mathrm{r} / \mathrm{w}$ ratio, and zone refining [59]. The authors emphasized the significance of the final depositional conditions and evolution of mound and vent structures rather than the original geochemistry of the hydrothermal fluid; the composition of the substrate may become relevant in subseafloor mineralization, where sulphides are precipitated by the reaction of ascending hydrothermal fluids with substrate host rocks [59]. Individual deposits may show a mixture of geochemical signatures, which may be related to mafic and ultramafic rocks $[19,58]$. Assuming that the leaching of elements from substrate rocks is influenced by the structure of the oceanic lithosphere and by the nature of the hydrothermal convection (spreading rate), some specific geochemical features, such as $\mathrm{Au}$ enrichment, $\mathrm{Au} / \mathrm{Ag}$ and $\mathrm{Co} / \mathrm{Ni}$ ratios, may be related to the nature of the substrate, the presence of a magmatic influx of volatiles and metals, the morphology of vent structures, the ridge spreading rate, or a combination of these factors $[19,58,59]$. Although the observed textural and mineralogical features (Figures 3-5) are inconsistent with an origin of the sulphides at magmatic temperatures, the recorded differences, such as the higher $\mathrm{Zn}$, Se, Mo, $\mathrm{Au}, \mathrm{Ag}, \mathrm{Hg}$, and $\mathrm{Sb}$ and lower Ni contents in the Pindos compared to the Othrys sulphides (Table 3; Figure 6), may reflect inheritance of a primary magmatic signature.

\subsection{Genetic Significance of Trace Elements}

The massive Cyprus-type sulphides from the Kondro Hill are characterized by elevated Zn, Co, $\mathrm{Se}, \mathrm{Au}, \mathrm{As}, \mathrm{Ag}, \mathrm{Mo}$, and Sb content (Table 1) compared to those of the Othrys and most of the Troodos sulphide ores (Figure 6). Apart from the major elements, namely $\mathrm{Fe}, \mathrm{Cu}$, and $\mathrm{Zn}$, hosted in pyrite, 
chalcopyrite, bornite, and sphalerite, Au occurs as submicroscopic particles $(<1 \mu \mathrm{m})$ in grains of As-bearing pyrite, chalcopyrite, and bornite [20,26]. Selenium and Te are found as individual fine minerals, such as selenides (clausthalite) and tellurides (melonite) in Cu minerals (Figure 2f; [26]). Although Se can be easily hosted as a solid solution in high-temperature chalcopyrite [58], the presence of clausthalite in a late generation of fine-grained chalcopyrite-sphalerite intergrowths, penetrating into an earlier stage ore, may indicate re-distribution of Se. A late growth of clausthalite is also supported by the occurrence of clausthalite and tellurides filling cracks in pyrite and Cu minerals [26]. Furthermore, on the basis of thermodynamic calculations, it has been demonstrated that the presence of selenides in the oxidation zones of sulphide ores of Uralian VMS deposits is related to their stability under oxidizing conditions [60]. Molybdenite or other visible Mo minerals in the Pindos and Othrys sulphides have not yet been reported. It has been established that Mo displays siderophile, chalcophile, and lithophile behavior, depending on the composition of the system (including $\mathrm{fO}_{2}$ and $f S_{2}$ ), temperature, and pressure [61]. Further research is required to define the potential presence of invisible Mo minerals (less than $1 \mu$ ) in the Pindos sulphide-magnetite ores.

\subsection{Stability of Sulphides}

A salient feature of the sulphide minerals is a varying stability. The occurrence of euhedral pyrite crystals, in contrast to microcrystalline unhedral $\mathrm{Cu}$ and $\mathrm{Zn}$ sulphides (Figure 2), may indicate that pyrite was more stable during subsequent modification of the orebody. Although early large crystals of pyrite may be replaced by chalcopyrite or bornite and Fe-poor sphalerite intergrowths (Figure 2), the formation of cruciform aggregates of secondary minerals occurs only on bornite surfaces (Figure $2 \mathrm{i}-1$ ), probably reflecting a difference in their stability. The preferential leaching of $\mathrm{Cu}$ and $\mathrm{Zn}$ sulphide phases and the neo-formation of high $\mathrm{Cu}$ sulphides on bornite in contrast to neighboring pyrite may be the result of a preferred dissolution of $\mathrm{Cu}$ sulphides over pyrite, due to differing surface potentials [62]. It has been suggested that bornite with sulfur in excess (x-bornite) is stable at high temperature [62]. The authors of this study show that if the so-called sulfur-rich bornites are annealed at lower temperature, chalcopyrite or chalcopyrite and digenite exsolve, depending on the annealing temperature and composition. In addition to this exsolution, a new phase forms below approximately $140^{\circ} \mathrm{C}$, which is referred to as $\mathrm{x}$-bornite, and it is a metastable phase. Although $\mathrm{x}$-bornite is a metastable phase, the presented data (Figure 2i-l; Table 1) may confirm that $\mathrm{x}$-bornite can remain for a long time in natural environments, and epigenetic minerals, with a stoichiometry resembling geerite or spionkopite $[63,64]$, can be formed under environmental conditions in a short time.

\section{Conclusions}

The compilation of the mineralogical, geochemical, and mineral chemistry data from the sulphide occurrences hosted in the Pindos ophiolite complex and those from other ophiolites lead us to the following conclusions:

- $\quad$ Elevated contents of Au as invisible submicroscopic Au in pyrite and Cu minerals in the Pindos sulphides may reflect main collectors of $\mathrm{Au}$ at the time of the sulphide mineralization.

- The occurrence of clausthalite $(\mathrm{PbSe})$ and fine-grained gold in chalcopytite-bornite-sphalerite intergrowths of a subsequent stage mineralization in the Pindos sulphides indicates their re-mobilization/re-deposition.

- $\quad$ Sulphides (pyrrhotite, chalcopyrite, bornite, and sphalerite) associated with magnetite, at deeper parts of the Pindos (Tsoumes), exhibit $\mathrm{Cu} /(\mathrm{Cu}+\mathrm{Ni}), \mathrm{Ni} / \mathrm{Co}$, and $\mathrm{Pt} /(\mathrm{Pt}+\mathrm{Pd})$ ratios, suggesting either no magmatic origin or a complete transformation of a preexisting magmatic assemblages.

- Textural features and the presence of the $(\mathrm{Fe} / \mathrm{Mg}$ ) phyllosilicate resembling $\mathrm{Mg}-$ hisingerite, and calcite in the matrix of the Pindos sulphides, suggest precipitation of the sulphide-magnetite ore at the deeper levels from a Fe-rich and alkaline ore-forming system. 
- The preferential leaching of Fe and $\mathrm{S}$ and neo-formed high $\mathrm{Cu}$ sulphides on bornite, in contrast to neighboring pyrite, may be the result of a preferred dissolution of $\mathrm{Cu}$ sulphides over pyrite, confirming literature data on differing surface potentials between those sulphides.

- Assuming that trace elements in epigenetic minerals are derived from the decomposition of primary minerals, and coupled with the higher $\mathrm{Zn}, \mathrm{Se}, \mathrm{Mo}, \mathrm{Au}, \mathrm{Ag}, \mathrm{Hg}$, and $\mathrm{Sb}$ and lower $\mathrm{Ni}$ contents in the Pindos compared to the Othrys sulphides, this may reflect inheritance of a primary magmatic signature.

Author Contributions: D.G.E., M.E.-E., and G.E. collected the samples, provided the field information, and contributed to the conceptualization of the manuscript. V.S. performed the SEM/EDS analyses. M.E.-E. discussed the mineralogical and chemical data with the co-authors and carried out the original draft of the manuscript. All authors have read and agreed to the published version of the manuscript.

Funding: The National and Kapodistrian University of Athens (NKUA) is greatly acknowledged for the financial support (Grant No. KE_11730) of this work.

Acknowledgments: We thank the reviewers for the constructive criticism and suggestions on an earlier draft of the manuscript. In particular, the review of this work by the Academic Editor Paolo Nimis is greatly appreciated. Many thanks are due to our colleague Costas Mparlas for the donation of certain sulphide samples from his collection and valuable discussions.

Conflicts of Interest: The authors declare no conflict of interest.

\section{References}

1. Hannington, M.; Herzig, P.; Scott, S.; Thompson, G.; Rona, P. Comparative mineralogy and geochemistry of gold-bearing sulfide deposits on the mid-ocean ridges. Mar. Geol. 1991, 101, 217-248. [CrossRef]

2. Franklin, J.M.; Sangster, D.M.; Lydon, J.W. Volcanic-associated massive sulfide deposits. Econ. Geol. 1991, 75, $485-627$.

3. Hannington, M.D.; Galley, A.; Gerzig, P.; Petersen, S. Comparison of the TAG mound and stockwork complex with Cyprus-type massive sulfide deposits. Proc. Ocean Drill. Program 1998, 158, 389-415.

4. Barrie, C.T.; Hannington, M.D. Classification of volcanic-associated massive sulfide deposits based on host-rock composition. In Volcanic-Associated Massive Sulfide Deposits: Processes and Examples in Modern and Ancient Settings; Society of Economic Geologists: Littleton, CO, USA, 1999; pp. 1-11.

5. Galley, A.; Hannington, M.; Jonasson, I. Volcanogenic massive sulphide deposits. mineral deposits of Canada Spec. Publ. 2007, 5, 141-161.

6. Nimis, P.; Zaykov, V.V.; Omenetto, P.; Melekestseva, I.Y.; Tesalina, S.G.; Orgeval, J.J. Peculiarities of some mafic-ultramafic- and ultramafic-hosted massive sulfide deposits from the Main Uralian Fault Zone, southern Urals. Ore Geol. Rev. 2008, 33, 49-69. [CrossRef]

7. Yıldırım, N.; Dönmez, C.; Kang, J.; Lee, I.; Pirajno, F.; Yıldırım, E.; Günay, K.; Seo, J.H.; Farquhar, J.; Chang, S.W. A magnetite-rich Cyprus-type VMS deposit in Ortaklar: A unique VMS style in the 1373 Tethyan metallogenic belt, Gaziantep, Turkey. Ore Geol. Rev. 2016, 79, 425-442. [CrossRef]

8. Toffolo, L.; Nimis, P.; Martin, S.; Tumiati, S.; Bach, W. The Cogne magnetite deposit (Western Alps, Italy): A Late Jurassic seafloor ultramafic-hosted hydrothermal system? Ore Geol. Rev. 2017, 83, 103-126. [CrossRef]

9. Foose, M.P. The Setting of a Magmatic Sulfide Occurrence in a Dismembered Ophiolite, Southwest Oregon; Distribution Branch, USA Geological Survey: Reston, VA, USA, 1985; p. 1626.

10. Bacuta, G.C.; Kay, R.W.; Gibbs, A.K.; Lipin, B.R. Platinum-group element abundance and distribution in chromite deposits of the Acoje Block. Zambales ophiolite Complex, Philippines. J. Geochem. Explor. 1990, 37, 113-145. [CrossRef]

11. Lachize, M.; Lorand, J.P.; Juteau, T. Calc-alkaline differentiation trend in the plutonic sequence of the Wadi Haymiliyah section, Haylayn Massif, Semail Ophiolite, Oman. Lithos 1996, 38, 207-232. [CrossRef]

12. Karaj, N. Reportition des platinoides chromites et sulphures dans le massif de Bulqiza, Albania. In Incidence sur le Processus Metallogeniques dans les Ophiolites (These); Universite de Orleans: Orleans, France, 1992; p. 379.

13. Prichard, H.M.; Lord, R.A. A model to explain the occurrence of platinum- and palladium-rich 3065 ophiolite complexes. J. Geol. Soc. 1996, 153, 323-328. [CrossRef] 
14. Proenza, J.A.; Gervilla, F.; Melgarejo, J.; Vera, O.; Alfonso, P.; Fallick, A. Genesis of sulfide-rich chromite ores by the interaction between chromitite and pegmatitic olivine-norite dikes in the Potosí Mine (Moa-Baracoa ophiolitic massif, eastern Cuba). Miner. Depos. 2001, 36, 658-669. [CrossRef]

15. Panayiotou, A. Cu-Ni-Co-Fe Sulphide Mineralization, Limassol Forest, Cyprus; Panayiotou, A., Ed.; Intern. Ophiolite Symposium: Nicosia, Cyprus, 1980; pp. 102-116.

16. Economou, M.; Naldrett, A.J. Sulfides associated with podiform bodies of chromite at Tsangli, Eretria, Greece. Miner. Depos. 1984, 19, 289-297. [CrossRef]

17. Thalhammer, O.; Stumpfl, E.F.; Panayiotou, A. Postmagmatic, hydrothermal origin of sulfide and arsenide mineralizations at Limassol Forest, Cyprus. Miner. Depos. 1986, 21, 95-105. [CrossRef]

18. Foose, M.P.; Economou, M.; Panayotou, A. Compositional and mineralogic constraints in the Limassol Forest portion of the Troodos ophiolite complex, Cyprus. Miner. Depos. 1985, 20, 234-240. [CrossRef]

19. Melekestzeva, I.Y.; Zaykov, V.V.; Nimis, P.; Tret'yakov, G.A.; Tessalina, S.G. Cu-(Ni-Co-Au)- bearing massive sulfide deposits associated with mafic-ultramafic rocks of the Main Urals Fault, South Urals: Geological structures, ore textural and mineralogical features, comparison with modern analogs. Ore Geol. Rev. 2013, 52, 18-36. [CrossRef]

20. Economou-Eliopoulos, M.; Eliopoulos, D.; Chryssoulis, S. A comparison of high-Au massive sulfide ores hosted in ophiolite complexes of the Balkan Peninsula with modern analogues: Genetic significance. Ore Geol. Rev. 2008, 33, 81-100. [CrossRef]

21. Kostopoulos, D.K. Geochemistry, Petrogenesis and Tectonic Setting of the Pindos Ophiolite, NW Greece. Ph.D. Thesis, Univ. of Newcastle, Newcastle, UK, 1989.

22. Jones, G.; Robertson, A.H.F. Tectono-stratigraphy and evolution of the Mesozoic Pindos ophiolite and related units, northwestern Greece. J. Geol. Soc. Lond. 1991, 148, 267-288. [CrossRef]

23. Pe-Piper, G.; Tsikouras, B.; Hatzipanagiotou, K. Evolution of boninites and island-arc tholeiites in the Pindos ophiolite, Greece. Geol. Mag. 2004, 141, 455-469. [CrossRef]

24. Kapsiotis, A.; Grammatikopoulos, T.; Tsikouras, B.; Hatzipanagiotou, K.; Zaccarini, F.; Garuti, G. Chromian spinel composition and Platinum-group element mineralogy of chromitites from the Milia area, Pindos ophiolite complex, Greece. Can. Miner. 2009, 47, 1037-1056. [CrossRef]

25. Skounakis, S.; Economou, M.; Sideris, C. The ophiolite complex of Smolicas and the associated Cu-sulfide deposits. In Proceedings, International Symposium on the Metallogeny of Mafic and Ultramafic Complexes, UNESCO, GCP Project 169; Augoustidis, S.S., Ed.; Theophrastus Publications S.A.: Athens, Greece, 1980; Volume 2, pp. 361-374.

26. Barlas, C.; Economou-Eliopoulos, M.; Skounakis, S. Selenium-bearing minerals in massive sulfide ore from the Pindos ophiolite complex. In Mineral. Deposits at the Beginning of the 21st Century; Piestrzyiski, A., Ed.; CRC Press: Rotterdam, The Netherlands, 2001; pp. 565-568.

27. Sideris, C.; Skounakis, S.; Laskou, M.; Economou, M. Brecciated pipeform diabase from the Pindos ophiolite complex. Chem. Der Erde 1984, 43, 189-195.

28. Tutolo, B.M.; Evans, B.W.; Kuehner, S.M. Serpentine-hisingerite solid solution in altered ferroan peridotite and olivine gabbro. Minerals 2019, 9, 47. [CrossRef]

29. Metsios, C. Metsios, C. Mobility of selenium-Environmental Impact. Master's Thesis, National University of Athens, Athens, Greece, 1999; 132p. (In Greek)

30. Constantinou, G. Metalogenesis associated with Troodos ophiolite. In Proceedings of the International Ophiolite Synposium, Nicosia, Cyprus, 1-8 April 1979; pp. 663-674.

31. Constantinou, G.; Govett, G.J.S. Genesis of sulphide deposits, ochre and umber of Cyprus. Trans. Inst. Min. Met. 1972, 81, B34-B46.

32. Rassios, A. Geology and copper mineralization of the Vrinena area, east Othris ophiolite, Greece. Ofioliti 1990, 15, 287-304.

33. Robertson, A.H.F.; Varnavas, S.P. The origin of hydrothermal metalliferous sediments associated with the early Mesozoic Othris and Pindos ophiolites, mainland Greece. Sediment. Geol. 1993, 83, 87-113. [CrossRef]

34. Naldrett, A. Magmatic Sulfide Deposits—Geology, Geochemistry and Exploration; Springer: Heidelberg, NY, USA, 2004; pp. 1-727.

35. Barnes, S.J.; Mungall, J.E.; Le Vaillant, M.; Godel, B.; Lesher, C.M.; Holwell, D.; Lightfoot, P.C.; Krivolutskaya, N.; Wei, B. Sulfide-silicate textures in magmatic Ni-Cu-PGE sulfide ore deposits: Disseminated and net-textured ores. Am. Miner. 2017, 102, 473-506. [CrossRef] 
36. Naldrett, A.J.; Barnes, S.-J. The behaviour of platinum group elements during fractional crystallization and partial melting with special reference to the composition of magmatic sulfide ores. Fortschr. Miner. 1986, 63, 113-133.

37. Maier, W.D.; Barnes, S.J.; Campbell, I.H.; Fiorentini, M.L.; Peltonen, P.; Barnes, S.J.; Smithies, R.H. Progressive mixing of meteoritic veneer into the early Earth's deep mantle. Nature 2009, 460, 620-623. [CrossRef]

38. Lesher, C.M.; Burnham, O.M.; Keays, R.R.; Barnes, S.J.; Hulbert, L. Trace-element geochemistry and petrogenesis of barren and ore-associated komatiites. Can. Miner. 2001, 39, 673-696. [CrossRef]

39. Barnes, S.-J.; Prichard, H.M.; Cox, R.A.; Fisher, P.C.; Godel, B. The location of the chalcophile and siderophile elements in platinum-group element ore deposits (atextural, microbeam and whole rock geochemical study): Implications for the formationof the deposits. Chem. Geol. 2008, 248, 295-317. [CrossRef]

40. Hinchey, J.G.; Hattori, K.H. Magmatic mineralization and hydrothermal enrichment of the High Grade Zone at the Lac des Iles palladium mine, northern Ontario. Can. Miner. 2005, 40, 13-23. [CrossRef]

41. Su, S.G.; Lesher, C.M. Genesis of PGE mineralization in the Wengeqi mafic-ultramafic complex, Guyang County, Inner Mongolia, China. Miner. Depos. 2012, 47, 197-207. [CrossRef]

42. Naldrett, A.J. Nickel sulfide deposits: Classification, composition and genesis. Econ. Geol 1981, 75, 628-655.

43. Konnunaho, J.P.; Hanski, E.J.; Karinen, T.T.; Lahaye, Y.; Makkonen, H.V. The petrology and genesis of the Paleoproterozoic mafic intrusion-hosted Co-Cu-Ni deposit at Hietakero, NW Finnish Lapland. Bull. Geol. Soc. Finl. 2018, 90, 104-131. [CrossRef]

44. Shiga, Y. Behavior of iron, nickel, cobalt and sulfur during serpentinization, with reference to the Hayachine ultramafic rocks of the Kamaishi mining distric, northeastern Japan. Can. Miner. 1987, 25, 611-624.

45. Alt, J.C.; Shanks, W.C. Serpentinization of abyssal peridotites from the MARK area, Mid-Atlantic Ridge: Sulfur geochemistry and reaction modeling. Geochim. Cosmochim. Acta 2003, 67, 641-653. [CrossRef]

46. Etiope, G.; Ifandi, E.; Nazzari, M.; Procesi, M.; Tsikouras, B.; Ventura, G.; Steele, A.; Tardini, R.; Szatmari, P. Widespread abiotic methane in chromitites. Sci. Rep. 2018, 8, 8728. [CrossRef]

47. Economou-Eliopoulos, M.; Tsoupas, G.; Skounakis, V. Occurrence of graphite-like carbon in podiform chromitites of Greece and its genetic significance. Minerals 2019, 9, 152. [CrossRef]

48. Ifandi, E.; Zaccarini, Z.; Tsikouras, B.; Grammatikopoulos, T.; Garuti, G.; Karipi, S. First occurrences of $\mathrm{Ni}-\mathrm{V}-\mathrm{Co}$ phosphides in chromitite from the Agios Stefanos Mine, Othrys Ophiolite, Greece. Ofioliti 2018, 43, 131-145.

49. Zaccarini, F.; Bindi, L.; Ifandi, E.; Grammatikopoulos, T.; Stanley, C.; Garuti, G.; Mauro, D. Tsikourasite, Mo3Ni2P1 + x $(x<0.25)$, a new phosphide from the chromitite of the Othrys Ophiolite, Greece. Minerals 2019, 9, 248.

50. Bindi, L.; Zaccarini, F.; Ifandi, E.; Tsikouras, B.; Stanley, C.; Garuti, G.; Mauro, D. Grammatikopoulosite, NiVP, a new phosphide from the chromitite of the Othrys Ophiolite, Greece. Minerals 2020, 10, 131. [CrossRef]

51. Bindi, L.; Zaccarini, F.; Bonazzi, P.; Grammatikopoulos, T.; Tsikouras, B.; Stanley, C.; Garuti, G. Eliopoulosite, V7S8, a new sulfide from the podiform chromitite of the othrys ophiolite, Greece. Minerals 2020, 10, 245. [CrossRef]

52. Eggleton, R.A.; Tilley, D.B. Hisingerite: A ferric kaolin mineral with curved morphology. Clays Clay Miner. 1998, 46, 400-413. [CrossRef]

53. Wicks, F.J.; O'Hanley, D.S. Volume 19, hydrous phyllosilicates: Serpentine minerals: Structures and petrology. In Reviews in Mineralogy; BookCrafters: Chelsea, MI, USA, 1988; pp. 91-167.

54. Andreani, M.; Munoz, M.; Marcaillou, C.; Delacour, A. Mu XANES study of iron redox state in serpentine during oceanic serpentinization. Lithos 2013, 178, 70-83. [CrossRef]

55. Klein, F.; Bach, W.; Humphris, S.E.; Kahl, W.-A.; Jons, N.; Moskowitz, B.; Berquo, T.S. Magnetite in seafloor serpentinite-Some like it hot. Geology 2014, 42, 135-138. [CrossRef]

56. Bonnemains, D.; Carlut, J.; Escartı'n, J.; Me'vel, C.; Andreani, M.; Debret, B. Magnetic signatures of serpentinization at ophiolite complexes. Geochem. Geophys. Geosyst. 2016, 17, 2969-2986. [CrossRef]

57. Eliopoulos, D.; Economou-Eliopoulos, M. Trace element distribution in magnetite separates of varying origin: Genetic and exploration significance. Minerals 2019, 9, 759. [CrossRef]

58. Marques, A.F.A.; Barriga, F.; Scott, S.D. Sulfide mineralization in an ultramafic-rock hosted seafloor hydrothermal system: From serpentinization to the formation of $\mathrm{Cu}-\mathrm{Zn}-(\mathrm{Co})$-rich massive sulfides. Mar. Geol. 2007, 245, 20-39. [CrossRef] 
59. Toffolo, L.; Nimis, P.; Tret'yakov, G.A.; Melekestseva, I.Y.; Beltenev, V.E. Seafloor massive sulfides from mid-ocean ridges: Exploring the causes of their geochemical variability with multivariate analysis. Earth-Sci. Rev. 2020, in press. [CrossRef]

60. Belogub, E.V.; Ayupovaa, N.R.; Krivovichevb, V.G.; Novoselov, K.A.; Blinov, I.A.; Charykova, M.V. Se minerals in the continental and submarine oxidation zones of the South Urals volcanogenic-hosted massive sulfide deposits: A review. Ore Geol. Rev. 2020, 122, 103500. [CrossRef]

61. Fitton, J.G. Coupled molybdenum and niobium depletion in continental basalts. Earth Planet. Sci. Lett. 1995, 136, 715-721. [CrossRef]

62. Kullerud, G. The Cu-Fe-S system. In Washington Year Book; Carnegie Institution of Washington: Washington, DC, USA, 1964; Volume 63, pp. 200-202.

63. Goble, J.; Robinson, G. Geerite, $\mathrm{Cu}_{1.60} \mathrm{~S}$, a new copper sulfide from Dekalb Township, New York. Can. Miner. 1980, 18, 519-523.

64. Goble, J.R. Copper sulfides from Alberta: Yarrowite $\mathrm{Cu}_{9} \mathrm{~S}_{8}$ and Spionkopite $\mathrm{Cu}_{39} \mathrm{~S}_{28}$. Can. Miner. 1980, $18,511-518$.

(C) 2020 by the authors. Licensee MDPI, Basel, Switzerland. This article is an open access article distributed under the terms and conditions of the Creative Commons Attribution (CC BY) license (http://creativecommons.org/licenses/by/4.0/). 